\title{
Mechanical behaviour of low-medium density destructured White Chalk
}

\author{
F. ALVAREZ-BORGES*, B. N. MADHUSUDHAN† and D. J. RICHARDS
}

\begin{abstract}
Low- and medium-density White Chalk often destructures during civil engineering works, forming a putty that exhibits problematic low strengths in the short term but may build-up strength with time. The underlying mechanisms that control the mechanical performance of the material are not well understood. This paper explores the prospect of developing a framework to characterise the behaviour of chalk putty. To this end, triaxial tests were carried out using low- and medium-density reconstituted chalks produced by different methods. Using void ratio against mean effective stress results, a unique critical state line (CSL) is proposed, regardless of parent rock origin or the crushing process used to generate the putty material. The CSL was also found to satisfactorily fit independent test data by various authors, even though each independent sample material may have had different 'intrinsic' CSLs. This was suggested to stem from the similar particle characteristics of the chalks used. An assessment of the ageing effect indicates increases in strength as a result of densification due to consolidation and secondary compression, however, the end-of-test state could still be described using the CSL.
\end{abstract}

KEYWORDS: calcareous soils; chalk; shear strength

Published with permission by the ICE under the CC-BY 4.0 license. (http://creativecommons.org/licenses/by/4.0/)

\section{NOTATION}

$C_{\alpha} \quad$ coefficient of secondary compression

e void ratio

$K_{0} \quad$ ratio of vertical to radial effective stress in vertical zero-radial strain compression

$M \quad$ ratio between $q$ and $p^{\prime}$ at critical state

$p^{\prime} \quad$ mean effective stress: $\left(\sigma_{1}^{\prime}+\sigma_{2}^{\prime}+\sigma_{3}^{\prime}\right) / 3$

$p_{\mathrm{c}}^{\prime}$ mean effective stress on the critical state line (CSL) at current void ratio

$p_{\text {ref }}^{\prime}$ reference mean effective stress $=1 \mathrm{kPa}$

$q$ deviator stress. Triaxial tests $=\sigma_{1}^{\prime}-\sigma_{3}^{\prime}$

$u$ pore-water pressure

$w$ water content

$\varepsilon_{\text {ax }}$ axial strain in triaxial tests

$\sigma_{1}^{\prime} \quad$ major principal stress

$\sigma_{2}^{\prime}$ intermediate principal stress

$\sigma_{3}^{\prime} \quad$ minor principal stress

$\phi_{\mathrm{c}}^{\prime} \quad$ critical state angle of friction

\section{INTRODUCTION}

Civil engineering works in low- and medium-density Chalk often mechanically destructure the material, forming a puttylike mixture of whole and broken coccoliths (Lake, 1975; Clayton, 1978). This 'chalk putty' exhibits low strengths in the short term but may build-up strength with time (Bialowas et al., 2018). Chalk putty may be encountered at the interface between foundation elements and the Chalk formation, like

Manuscript received 29 January 2020; first decision 22 April 2020; accepted 23 April 2020.

Published online at www.geotechniqueletters.com on 26 May 2020.

*Diamond Light Source Ltd., Didcot, Oxfordshire, UK

(Orcid:0000-0002-6940-9918).

$\uparrow$ Faculty of Engineering and Physical Sciences, University of Southampton, Southampton, UK (Orcid:0000-0002-2570-5934).

Faculty of Engineering and Physical Sciences, University of Southampton, Southampton, UK (Orcid:0000-0002-3819-7297). the chalk putty 'annulus' formed around driven piles on installation (Hobbs \& Atkinson, 1993; Lord et al., 2002). In these cases, foundation capacity may be dependent on the strength of chalk putty, but there is limited knowledge of its mechanical behaviour. However, there is evidence that destructured chalk is principally a silt and clay-sized largely non-plastic granular material (Clayton, 1983; Razoaki, 2000; Doughty, 2016; Bialowas, 2017), and it can be reasonably expected that its failure states are described by critical state concepts (Leddra, 1989; Leddra \& Jones, 1990; Burland, 1990a; Lord et al., 1994). However, previous critical state characterisation efforts have yielded multiple critical state lines (CSLs) suitable to specific material characteristics and testing conditions (e.g. Bialowas \& Diambra, 2018; Doughty et al., 2018; Alvarez-Borges et al., 2018b). From this perspective, this paper presents a laboratory investigation on destructured low-medium density White Chalk aimed at examining the suitability of a critical state framework to describe its mechanical behaviour.

\section{MATERIALS AND METHODS}

\section{Destructured chalk preparation}

Intact chalk samples were collected at two sites in southern England: Somborne Chalk Quarry (SOM) in Hampshire, and a quarry near St. Nicholas-at-Wade (SNW), in Kent. The samples were extracted from the Newhaven and Seaford Chalk formations, respectively. Additional sampling site information is available in Alvarez-Borges (2014), Bialowas (2017) and Buckley et al. (2018).

Two different destructuration methods were applied to each of the intact chalk samples. Method A comprised the use of a food (cheese) grater to disaggregate oven-dried blocks about $5 \mathrm{~cm}$ in diameter, while method B involved the use of a manual food grinder (meat mincer) to crush saturated gravel-sized lumps. Dry and wet sieving through the $425 \mu \mathrm{m}$ mesh was applied to the product of methods $\mathrm{A}$ and $\mathrm{B}$, respectively. The material from both methods was stored wet in sealed bags for about four weeks prior to 
Table 1. Sample index parameters (intact chalk data shown in italics)

\begin{tabular}{l|l|l|l|l}
\hline & SNW-A & SNW-B & SOM-A & SOM-B \\
\hline Formation & Seaford & Seaford & Newhaven & Newhaven \\
Mean IDD: $M g / m^{3 *}$ & $1 \cdot 57 \pm 0 \cdot 08$ & $1 \cdot 57 \pm 0 \cdot 08$ & $1 \cdot 47 \pm 0 \cdot 02$ & $1 \cdot 47 \pm 0 \cdot 02$ \\
Calcium carbonate content: \%† & $\approx 98 \cdot 2$ & $\approx 98 \cdot 2$ & $\approx 98 \cdot 5$ & $\approx 98 \cdot 5$ \\
Crushing method & $\mathrm{A}$ & $\mathrm{B}$ & $\mathrm{A}$ & $\mathrm{B}$ \\
Liquid limit: \% & 29 & 28 & 30 & 31 \\
Plastic limit: \% & 22 & 22 & 23 & 22 \\
$d_{50}: \mu \mathrm{m}$ & $4 \cdot 8$ & $4 \cdot 9$ & $5 \cdot 4$ & $4 \cdot 7$ \\
$d_{10}: \mu \mathrm{m}$ & $1 \cdot 4$ & $1 \cdot 4$ & $1 \cdot 5$ & $1 \cdot 5$ \\
$d_{60} / d_{10}$ & $5 \cdot 1$ & $4 \cdot 8$ & $5 \cdot 0$ & $4 \cdot 3$ \\
\hline
\end{tabular}

*IDD = intact dry density; measured using gas jar method by Clayton (1983).

$\dagger$ Based on Hancock (1975).

specimen preparation, to promote calcium carbonate $\left(\mathrm{CaCO}_{3}\right)$ dissolution, as discussed by Bialowas (2017).

The use of these preparation procedures was expected to enable the comparison with consolidation data reported by Alvarez-Borges et al. (2018a), and to facilitate the assessment of the influence of the preparation method and material origin on the characteristics and shearing behaviour of chalk putty (Cuccovillo \& Coop, 1993; Vaughan, 1997). Index properties were determined in accordance to BS 1377-2:1990 (BSI, 1998b) and BS-ISO 13320:2009 (BS-ISO, 2009) and are listed in Table 1. Particle-size distribution (PSD) curves are given in Fig. 1. Scanning electron microscopy (SEM) images of the intact and destructured materials are shown in Fig. 2.

\section{Triaxial tests}

Consolidated undrained triaxial tests were conducted using a standard triaxial apparatus, as detailed in BS 1377-8:1990 (BSI, 1998a). Pore-water pressure $(u)$ transducers were connected to the top and bottom specimen drainage lines, and cell and back pressure were applied by way of digital pressure controllers. Specimens were $38 \mathrm{~mm}$ in diameter and $76 \mathrm{~mm}$ high and were locally instrumented with a submersible linear variable differential transformer (LVDT) to measure radial strain. Global axial displacements were measured by way of an externally mounted LVDT; axial loads were determined using a submersible load cell.

Specimens were prepared using chalk putty at water contents $(w)$ between 1 and 1.5 times the liquid limit, as advised by Burland (1990b). Excess water was removed from the sample bags prior to specimen preparation

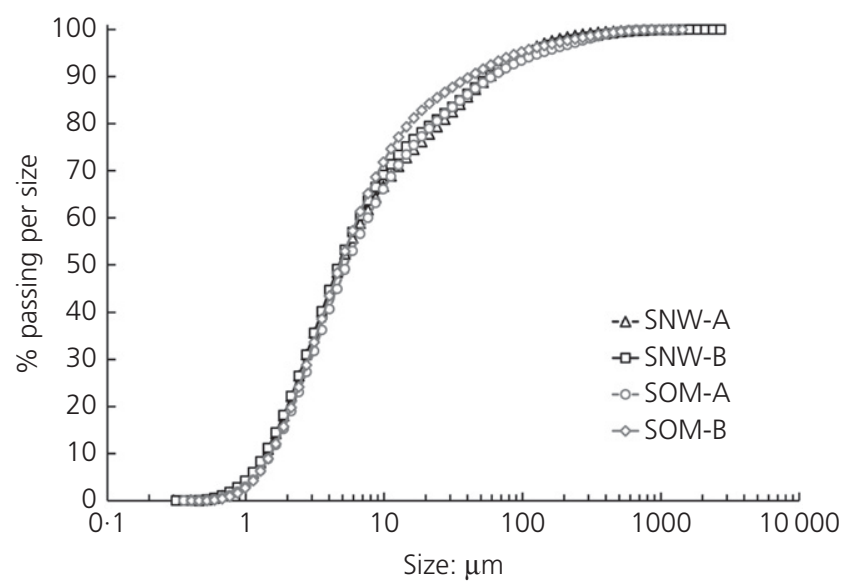

Fig. 1. Cumulative PSD curves of the four chalk putty samples and used to fill the back-pressure controller. The putty was thereafter transferred to a vacuum chamber for minimum $2 \mathrm{~h}$ and then used to fill a split-former assembled on the pedestal of the triaxial cell. The material was placed using a small spatula and gently stirred with a glass rod to remove air bubbles, as described by Doughty (2016). A small pre-consolidation stress $(\approx 7 \mathrm{kPa})$ was applied before removing the split former, to avoid large pre-test distortions. Back pressures between 300 and $400 \mathrm{kPa}$ were

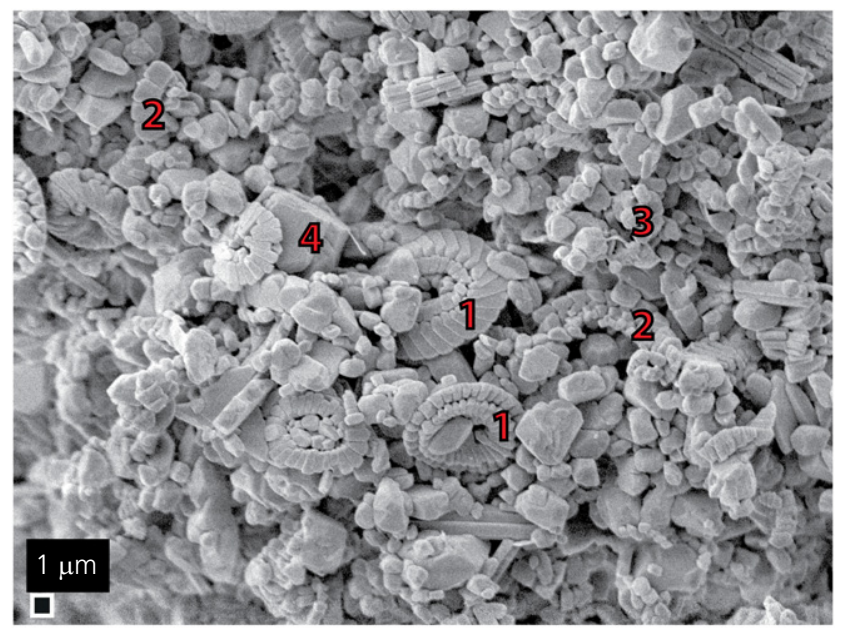

(a)

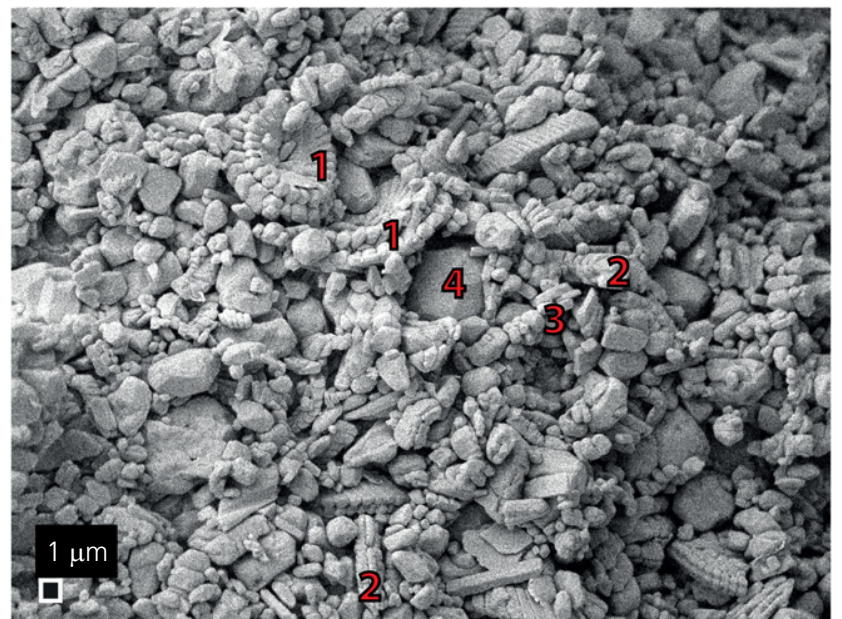

(b)

Fig. 2. SEM micrographs $(10000 x)$ of intact (a) and destructured (b) SNW chalk (method B): 1 - intact coccolith; 2 - broken coccolith; 3 - coccolithic platelets; 4 - authigenic calcite grain 
Table 2. Triaxial test details

\begin{tabular}{|c|c|c|c|c|c|c|c|c|c|c|}
\hline \multirow[b]{2}{*}{ Test number } & \multirow[b]{2}{*}{ Preparationdetails } & \multicolumn{3}{|c|}{ Pre-shear conditions } & \multirow[b]{2}{*}{ Ageing: days } & \multirow[b]{2}{*}{ Shear rate: $\% / h$} & \multicolumn{4}{|c|}{ Ultimate state } \\
\hline & & $p^{\prime}: \mathrm{kPa}$ & $q: \mathrm{kPa}$ & $e$ & & & $\mathrm{CS}^{*}$ & $p^{\prime} \dagger: \mathrm{kPa}$ & $q \dagger: \mathrm{kPa}$ & $\varphi^{\prime}:{ }^{\circ}$ \\
\hline 1 & SNW-B & 1762 & 1396 & 0.571 & $<1$ & $0 \cdot 1$ & No & 2894 & 4318 & $36 \cdot 7$ \\
\hline 2 & SNW-B & 1879 & 1648 & 0.585 & $<1$ & $0 \cdot 2$ & No & 2523 & 3696 & $36 \cdot 1$ \\
\hline 3 & SNW-B & 52 & 1 & 0.743 & $1 \cdot 7$ & $0 \cdot 2$ & Yes & 61 & 85 & $34 \cdot 4$ \\
\hline 4 & SNW-B & 268 & 16 & 0.674 & $<1$ & $0 \cdot 2$ & Yes & 515 & 726 & $34 \cdot 8$ \\
\hline 5 & SNW-B & 1301 & 2 & 0.630 & $1 \cdot 1$ & $0 \cdot 2$ & No & 1228 & 1644 & $33 \cdot 2$ \\
\hline 6 & SNW-B & 1306 & 3 & 0.670 & 13 & $0 \cdot 2$ & Yes & 713 & 983 & $34 \cdot 1$ \\
\hline 7 & SNW-A & 805 & 2 & 0.658 & $1 \cdot 8$ & $0 \cdot 2$ & Yes & 649 & 821 & $31 \cdot 5$ \\
\hline 8 & SOM-B & 1904 & 1815 & 0.629 & $3 \cdot 7$ & $0 \cdot 2$ & No & 1502 & 2029 & $33 \cdot 5$ \\
\hline 9 & SOM-B & 1299 & 2 & 0.659 & $3 \cdot 6$ & $0 \cdot 2$ & Yes & 685 & 914 & $33 \cdot 1$ \\
\hline 10 & SOM-A & 1295 & 3 & 0.594 & $3 \cdot 2$ & $0 \cdot 2$ & Yes & 2057 & 2877 & $34 \cdot 6$ \\
\hline
\end{tabular}

*Critical state: Yes $=$ constant $p^{\prime}$ and $q$ attained before visible strain localisation; No $=$ constant $p^{\prime}$ and $q$ not attained at end of test.

$\dagger p^{\prime}=\left(\sigma_{1}^{\prime}+\sigma_{2}^{\prime}+\sigma_{3}^{\prime}\right) / 3$ (mean effective stress) and $q=\sigma_{1}^{\prime}-\sigma_{3}^{\prime}$ (deviator stress), where $\sigma_{1}^{\prime}, \sigma_{2}^{\prime}, \sigma_{3}^{\prime}$ are the principal effective stresses as customary.

then applied to achieve saturation $B$-values of about $0 \cdot 95$. Specimens were thereafter consolidated in isotropic (ISO) or one-dimensional (1D) fashion to targeted mean effective stress levels to attain pre-shear conditions qualitatively representative of 'loose' and 'dense' states. Consolidation stress levels and top-bottom drainage were maintained during varied time periods until axial creep rates reduced to less than about $0 \cdot 003 \% / \mathrm{h}$ (after Kuwano \& Jardine, 2002). Additionally, test 6 was maintained under constant $p^{\prime}$ in drained conditions for 13 days to investigate potential time-based gains in strength. All specimens were then sheared under strain control. Pre- and post-test specimen weight, $w$ and volume were used to derive in-test void ratios (e), as detailed by Madhusudhan \& Baudet (2014), using a specific gravity of $2 \cdot 70$, after Clayton (1983). Specimen details are presented in Table 2.

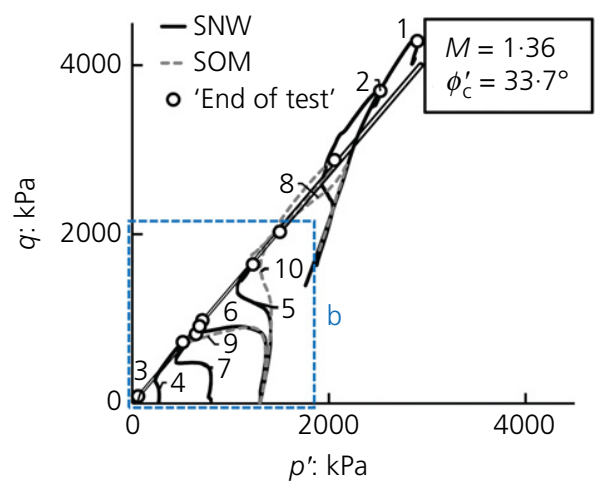

(a)

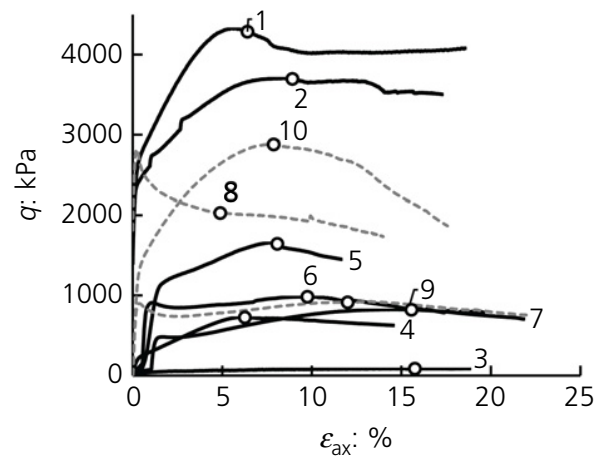

(c)

\section{RESULTS}

Figure 3 depicts stress paths in $q-p^{\prime}$ space (a), and $q$ - axial strain $\left(\varepsilon_{\mathrm{ax}}\right)(\mathrm{b})$ and $u-\varepsilon_{\mathrm{ax}}$ data (c). Most specimens exhibited contractive behaviour and effective stress reductions after yielding until reaching phase transformation (Ishihara et al., 1975), followed by a dilative response. As is often the case during triaxial testing involving standard porous end platens, strain localisation in the form of multiple conjugate shear bands was observed (Desrues \& Ando, 2015; Salvatore et al., 2017). The effect of strain localisation may be noted as a final stress path reversal from dilating to contracting in Fig. 3(a) (Burland, 1990b), and might have led to a modest underestimation of ultimate strengths (Lee, 1976). 'End-of-test' states are denoted by markers before this reversal. The term 'end of state' is preferred over 'critical state' because, in some cases, strain localisation prevented the

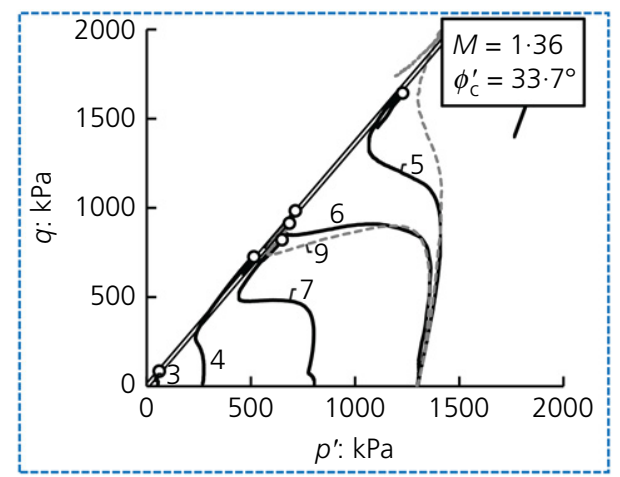

(b)

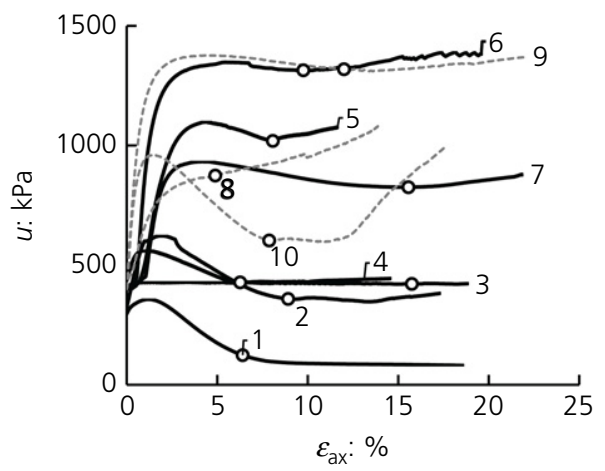

(d)

Fig. 3. Triaxial test results: (a) stress paths; (b) lower stress range in (a); (c) stress-strain curves; (d) pore-pressure evolution. Labels denote test number (Table 2) 


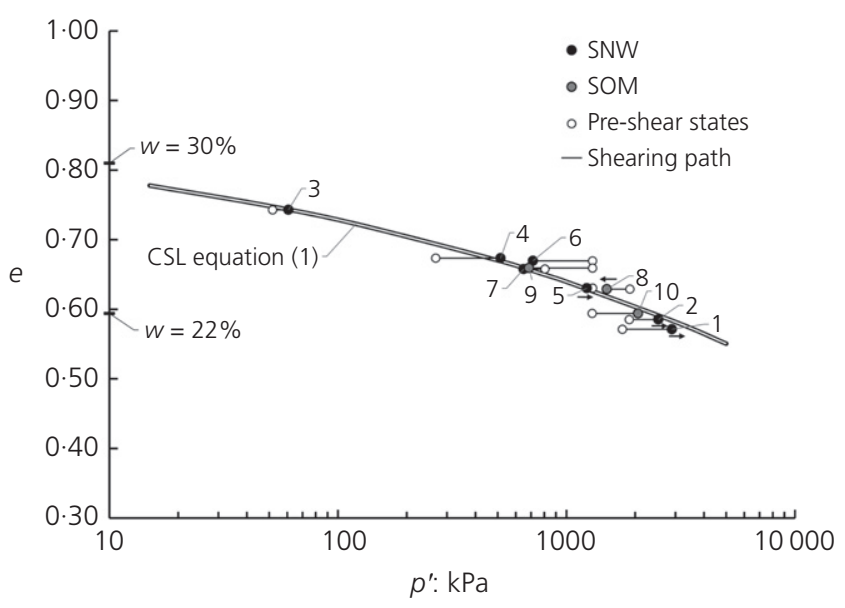

Fig. 4. Undrained triaxial shearing paths and ultimate states in In $p^{\prime}-e$ plane. Data labels denote test number (see Table 2)

attainment of global theoretical critical state conditions (i.e. shearing at constant $p^{\prime}, q$ and $e$; Roscoe et al., 1958). This is indicated in Table 2. It is acknowledged that strain localisation may have commenced before being detectable from global stress/strain measurements.

Figure 4 presents end-of-test states and stress paths in $e-\ln p^{\prime}$ space for all triaxial tests. Despite the limitations of strain localisation, a unique non-linear CSL may be proposed

$$
e=0.895-0.071\left(p^{\prime} / p_{\text {ref }}^{\prime}\right)^{0.186}
$$

where $p_{\text {ref }}^{\prime}=1 \mathrm{kPa}$ for dimensional consistency. Curved CSLs in $e-\ln p^{\prime}$ space are typical for many non-cohesive soils $(\mathrm{Li}$ \& Wang, 1998), though they are sometimes represented as linear for simplicity (Been et al., 1991).

The average critical state stress ratio $q / p^{\prime}=M$ derived from tests that globally appeared to reach critical state conditions was $1 \cdot 36$, equivalent to a critical state angle of friction $\left(\phi_{\mathrm{c}}^{\prime}\right)$ of $33.7^{\circ}$, which is comparable to previously reported values (30-35; Clayton, 1978; Razoaki, 2000; Doughty, 2016; Bialowas, 2017).

\section{DISCUSSION}

\section{General mechanical behaviour of chalk putty}

As for many sands, shearing behaviour appears to be substantially affected by pre-shear density. Specimens reconstituted at states 'loose' of the proposed CSL predominantly exhibited contractive behaviour on shearing (tests 6, 7, 8 and 9 in Figs 3 and 4), developing positive $u$ values. Conversely, dilative behaviours were encountered in dry side of critical experiments (tests 1, 2, 4 and 10 in Figs 3 and 4), with negative $u$ developments being predominant.

The proposed CSL (equation (1)) runs parallel to the 1D-NCL proposed by Alvarez-Borges et al. (2018a):

$$
e=0.928-0.071\left(p^{\prime} / p_{\text {ref }}^{\prime}\right)^{0.186}
$$

The suitability of these parallel state curves to characterise compression and shear behaviours suggests that the mechanical performance of chalk putty is not fundamentally different to that of monomineralic uniform sands (e.g. Coop \& Lee, 1993; Verdugo \& Ishihara, 1996). As for these materials, the location of these curves in volumetric space is likely dependent on material characteristics such as PSD, particle shape, mineralogy and so on. The parent low -medium density White Chalk rocks used were largely composed of calcareous coccolithic debris, and Fig. 2 evidences

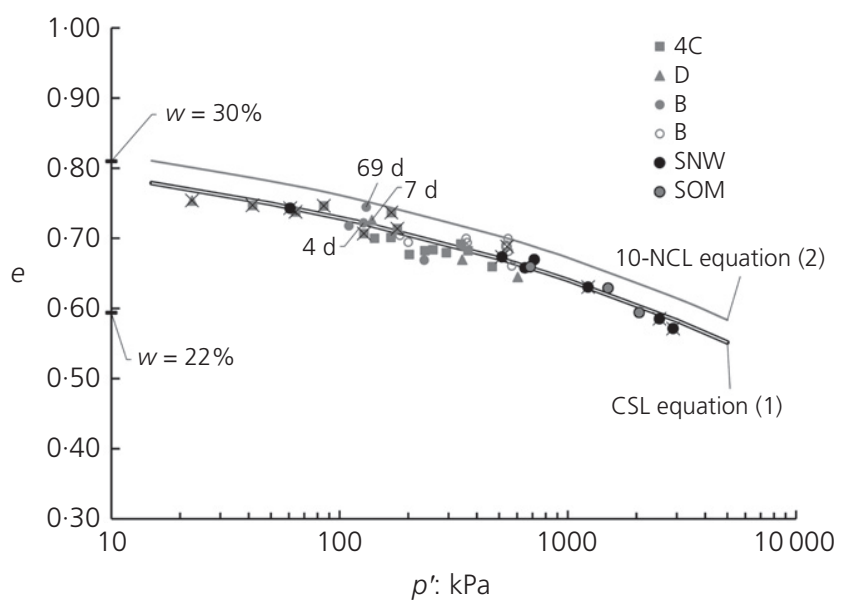

Fig. 5. Comparison between end-of-test states from triaxial experiments by various authors (see Table 3 for legend key) and tests 1-10 of this paper (SNW and SOM). Open and filled markers denote drained and undrained test data, respectively; crossed markers refer to short-term conditions; 'd' refers to days (see Table 4)

that the destructuration methods employed mainly entailed the disaggregation of these constitutive particles. This yielded putties with limited differences in PSD (Fig. 1), particle shape (Fig. 2) and mineralogy (Table 1), which explains the suitability of a single CSL for these materials.

\section{Chalk putty origin and the CSL}

Considering the suitability of a unique CSL to describe the failure states of the four tested putties, it may be postulated that putties created from similar parent intact chalks also have comparable particle characteristics and have a similar CSL. To examine this, end-of-test triaxial data by Clayton (1978), Doughty (2016) and Bialowas (2017) have been plotted in Fig. 5 alongside the results presented before. Ultimate state void ratios in the dataset by Doughty (2016) correspond to those recorded on specimen removal by the same author, which were felt to better reflect the global void ratio during shear. Sample details and end-of-test data are presented in Tables 3 and 4 .

Figure 5 evidences that the proposed CSL is a reasonable fit to the independent test data, even though each material had a different intrinsic CSL appropriate to their PSD. Such applicability of a single CSL to independent datasets is not encountered elsewhere in the Chalk literature. It is apparent that the underlying phenomena that controls the ultimate strength-volumetric state relationship of chalk putty are not substantially affected by the procedure used to crush the chalk, the variability of the parent low-medium density rock, the lower $p^{\prime}$ range used, or the differences in overall PSD (Fig. 6(a)). This is probably because low-medium density White Chalk fines exhibit limited differences in particle shapes and sizes (Fig. 6(b)), and this fine fraction controls the mechanical performance of crushed White Chalk when it accounts for at least $20 \%$ of its dry weight (Puig, 1973; Rat \& Schaeffner, 1990). Though some degree of grain breakage may have occurred during shear, the coarser fraction likely broke down into fines of similar characteristics to those tested in this study, while the fine fraction is expected to have exhibited limited comminution at the moderate stress levels used (see Alvarez-Borges et al., 2018a). In any event, particle breakage during shear seems to have been insufficient to significantly alter the suitability of the CSL in the compression plane. However, it must be emphasised that different particle characteristics introduced 
Table 3. Chalk putty index properties according to various researchers

\begin{tabular}{l|l|l|l|c|l|l|l|l}
\hline Author & $\begin{array}{l}\text { Sample } \\
\text { name }\end{array}$ & Sampling location & Formation & $\begin{array}{c}\text { Mean IDD: } \\
\mathrm{Mg}^{3} \mathrm{~m}^{3}\end{array}$ & $\begin{array}{l}\text { Preparation } \\
\text { method }\end{array}$ & $\begin{array}{l}\text { Grading } \\
\text { range }\end{array}$ & LL: \% & PL: \% \\
\hline $\begin{array}{c}\text { Clayton } \\
(1978)^{*}\end{array}$ & 4C & Swanley & Seaford & 1.43 & Oven-dry crushed & $<2 \mathrm{~mm}$ & $\mathrm{n} / \mathrm{a}$ & $\mathrm{n} / \mathrm{a}$ \\
$\begin{array}{c}\text { Doughty } \\
(2016) \dagger\end{array}$ & $\mathrm{D}$ & Wikinger & Maastrichtian & 1.50 & Saturated-crushed & Unrestricted $\ddagger$ & $33-38$ & $23-25$ \\
$\begin{array}{c}\text { Bialowas } \\
(2017)\end{array}$ & B & St. Nicholas-at-Wade & Margate & $\mathrm{n} / \mathrm{a}$ & Oven-dry crushed & Unrestricted $\ddagger$ & 30 & 22 \\
\hline
\end{tabular}

Note: see text for preparation method details.

*Old lithostratigraphy used by original author.

$\dagger$ Some material data obtained from Doughty et al. (2018).

t'Unrestricted grading' - that is, no sieving treatment was applied.

by diagenesis or destructuration may affect the observed behaviour. For instance, it is not expected that partially destructured chalk containing mostly coarse particles, crushed chalks produced from high intact dry density (IDD) rocks containing significant proportions of authigenic calcite grains, and materials containing important amounts of non-calcite minerals will share the same CSL given above.

Effect of ageing on the ultimate strength of chalk putty Figures 3 and 4 present results for tests 6,7 and 9 which were sheared at broadly similar void ratios, but aged for $13,1 \cdot 8$ and $3 \cdot 6$ days, in each case. Comparable end-of-test strengths

Table 4. Independent end-of-test triaxial data shown in Fig. 5

\begin{tabular}{|c|c|c|c|c|c|}
\hline Author & $\begin{array}{l}\text { Sample } \\
\text { name }\end{array}$ & $\begin{array}{l}\text { Ageing: } \\
\text { days }\end{array}$ & $\begin{array}{l}\text { Shearing } \\
\text { conditions }\end{array}$ & $\begin{array}{c}p^{\prime}: \\
\mathrm{kPa}\end{array}$ & $e$ \\
\hline \multirow{15}{*}{$\begin{array}{l}\text { Clayton } \\
\text { (1978) }\end{array}$} & $4 \mathrm{C}$ & $<1$ & Undrained & 42 & $0 \cdot 747$ \\
\hline & $4 \mathrm{C}$ & $<1$ & Undrained & 64 & 0.738 \\
\hline & $4 \mathrm{C}$ & $<1$ & Undrained & 85 & 0.746 \\
\hline & $4 \mathrm{C}$ & $<1$ & Undrained & 128 & 0.707 \\
\hline & $4 \mathrm{C}$ & $<1$ & Undrained & 179 & $0 \cdot 714$ \\
\hline & $4 \mathrm{C}$ & $<1$ & Undrained & 169 & 0.737 \\
\hline & $4 \mathrm{C}$ & 16 & Undrained & 168 & $0 \cdot 701$ \\
\hline & $4 \mathrm{C}$ & 16 & Undrained & 256 & 0.684 \\
\hline & $4 \mathrm{C}$ & 16 & Undrained & 340 & 0.692 \\
\hline & $4 \mathrm{C}$ & 20 & Undrained & 142 & $0 \cdot 700$ \\
\hline & $4 \mathrm{C}$ & 20 & Undrained & 236 & $0 \cdot 682$ \\
\hline & $4 \mathrm{C}$ & 20 & Undrained & 365 & $0 \cdot 682$ \\
\hline & $4 \mathrm{C}$ & 37 & Undrained & 202 & 0.677 \\
\hline & $4 \mathrm{C}$ & 37 & Undrained & 294 & $0 \cdot 680$ \\
\hline & $4 \mathrm{C}$ & 37 & Undrained & 466 & 0.660 \\
\hline \multirow{4}{*}{$\begin{array}{r}\text { Doughty } \\
(2016)\end{array}$} & D & $<1$ & Undrained & 23 & 0.75 \\
\hline & $\mathrm{D}$ & 7 & Undrained & 138 & 0.726 \\
\hline & D & 7 & Undrained & 603 & $0 \cdot 645$ \\
\hline & D & 14 & Undrained & 344 & $0 \cdot 670$ \\
\hline \multirow{16}{*}{$\begin{array}{c}\text { Bialowas } \\
(2017)\end{array}$} & B & 1 & Drained & 535 & 0.687 \\
\hline & B & 3 & Drained & 184 & $0 \cdot 704$ \\
\hline & B & 3 & Drained & 200 & 0.695 \\
\hline & B & 4 & Drained & 542 & $0 \cdot 688$ \\
\hline & B & 4 & Drained & 548 & $0 \cdot 682$ \\
\hline & B & 5 & Drained & 358 & $0 \cdot 700$ \\
\hline & B & 5 & Drained & 353 & $0 \cdot 687$ \\
\hline & B & 6 & Drained & 535 & 0.690 \\
\hline & B & 15 & Drained & 568 & $0 \cdot 661$ \\
\hline & B & 26 & Drained & 343 & $0 \cdot 690$ \\
\hline & B & 27 & Drained & 362 & $0 \cdot 694$ \\
\hline & B & 65 & Drained & 546 & $0 \cdot 700$ \\
\hline & B & 4 & Undrained & 127 & $0 \cdot 722$ \\
\hline & B & 5 & Undrained & 110 & $0 \cdot 718$ \\
\hline & B & 58 & Undrained & 235 & $0 \cdot 669$ \\
\hline & B & 69 & Undrained & 131 & 0.745 \\
\hline
\end{tabular}

consistent with the CSL are evident, regardless of whether the pre-shear $p^{\prime}-e$ conditions were attained by prolonged ageing or by subjecting an initially denser specimen to lower $p^{\prime}$ levels and/or a shorter consolidation period. Similar behaviour is observed using independent data from Doughty (2016) and Bialowas (2017), shown in Fig. 7 (Table 4). This figure denotes that ultimate states are not affected even by several weeks of drained ageing and considerably different pre-shear $p^{\prime}$ levels, and are instead dependent on the pre-shear void ratio. It is also evident from Figs 3(a) and 7 that ageing does not affect the magnitude of $\phi_{c}^{\prime}$. These

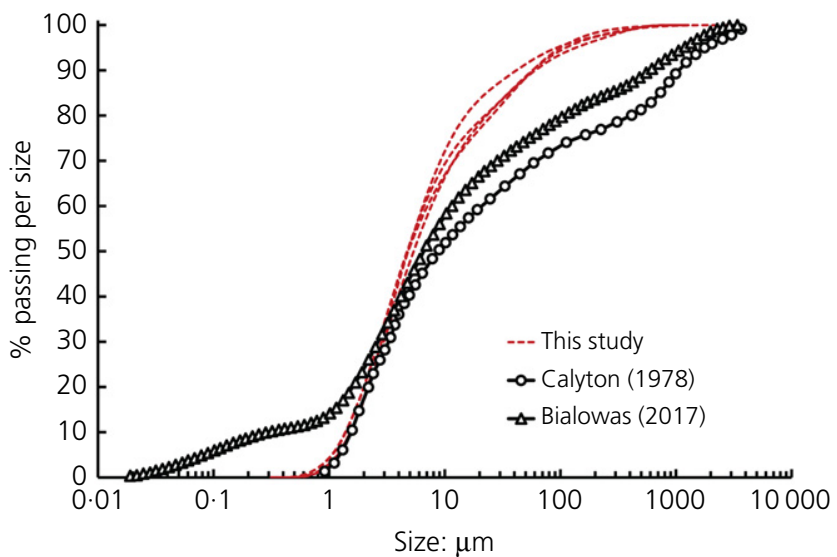

(a)

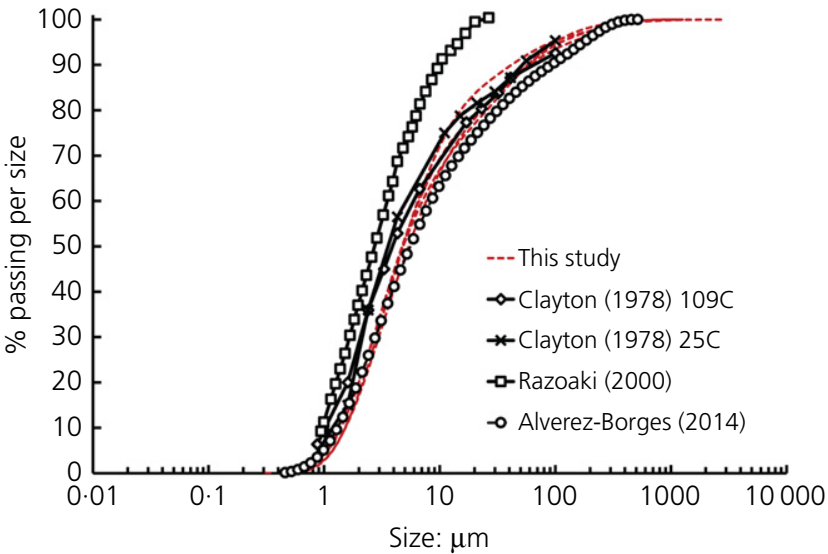

(b)

Fig. 6. (a) Cumulative PSD curves of crushed chalks studied by Clayton (1978) and Bialowas (2017); Note that the curve for the former has no grading restriction (Table 3). (b) Cumulative PSD curves of crushed chalks with $425 \mu \mathrm{m}$ upper size limit, from various authors 


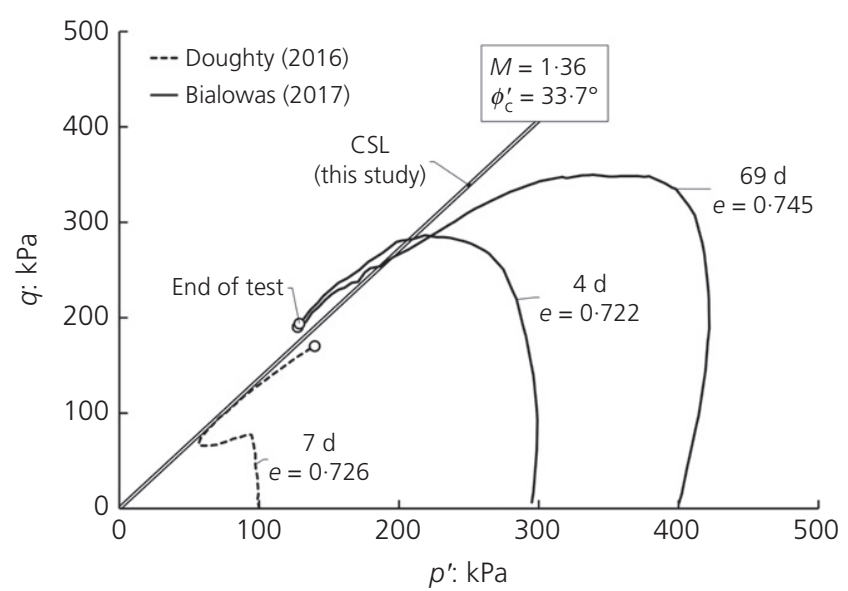

Fig. 7. Undrained triaxial test data from Doughty (2016) and Bialowas (2017) after various ageing periods ('d' refers to days; see Table 4). End-of-test conditions interpreted from graphs by the original authors

observations are consistent with the data presented in Fig. 5, which includes results from drained and undrained triaxial experiments involving various ageing periods (Table 4) and demonstrate for the first time that ageing does not alter the location of the CSL. This implies that any re-cementation by calcium carbonate precipitation during ageing is largely broken down during shearing and does not modify critical state parameters. Thus, the impact of chemically induced ageing is probably limited to small strain behaviour, as discussed by Bialowas (2017).

To explain improvements in large-strain chalk putty strength associated with ageing, Fig. 8(a) presents the volumetric compression path of test 6 , where reductions in void ratio while ageing at constant $p^{\prime}$ are evident. These void ratio reductions can be associated with an increment of the equivalent $p^{\prime}$ on the CSL at the current void ratio $\left(p_{\mathrm{c}}^{\prime}\right)$ of over $100 \%$, which may be linked with a similar increase in strength. Figure 8(b) shows that a significant portion of $p_{\mathrm{c}}^{\prime}$ increments in the time domain occur when the reduction in void ratio becomes approximately linear with the logarithm of time $\left(\Delta e / \Delta \log t=C_{\alpha}\right)$, a mechanism commonly interpreted as secondary compression (Mesri, 1973). It may be thus proposed that volumetric strains occurring during and after the end of primary compression result in an increment in ultimate strength compatible with the decrease in void ratio, and that these strains are a potential cause of the ageing or long-term 'strengthening' of destructured chalk.

\section{CONCLUSIONS}

A series of undrained triaxial experiments reveal a unique CSL for reconstituted White Chalk produced by two different methods from low-medium density parent rocks sampled from two locations. The underlying reason for the uniqueness of the CSL was proposed to be that the materials were largely constituted by coccolithic debris and exhibited a similar PSD. The proposed CSL was also found to be a reasonable fit for independent test data involving crushed chalks largely composed by fines and produced from similar chalk rocks, but exhibiting different PSDs. Chalk putty ageing was not observed to alter the suitability of the CSL, and ageing-related strength gains were proposed to be explained by void ratio reductions driven by consolidation and secondary compression. Overall, results support the use of the proposed CSL to characterise the general mechanical behaviour of the material, without disputing the fact that different intrinsic CSLs exist for materials of different PSD.

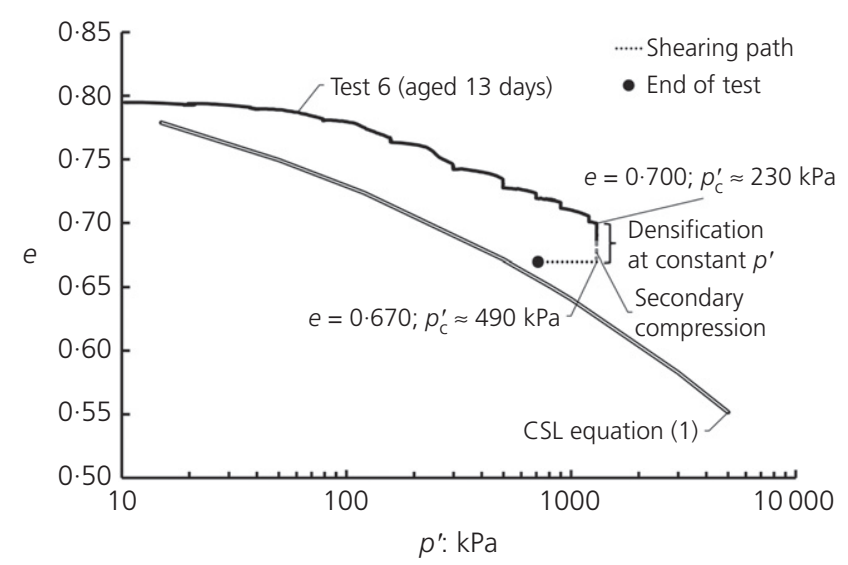

(a)

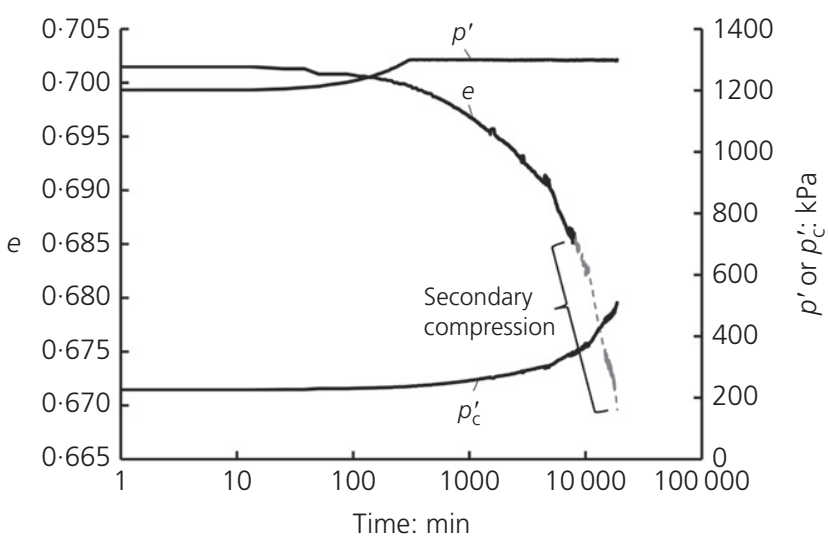

(b)

Fig. 8. (a) Volumetric compression path for test 6; (b) time-based decrease in $e$ and increase in $p_{c}^{\prime}$ during final $p^{\prime}$ ramp and ageing period

\section{ACKNOWLEDGEMENTS}

This research has been co-sponsored by the National Council of Science and Technology (CONACyT) of Mexico, and by the Faculty of Engineering and Physical Sciences of the University of Southampton.

\section{REFERENCES}

Alvarez-Borges, F. J. (2014). The application of simple shear testing to evaluate the shaft resistance on piles driven in chalk. MSc dissertation, University of Southampton, Southampton, UK.

Alvarez-Borges, F. J., Madhusudhan, B. N. \& Richards, D. J. (2018a). The 1D normal compression line and structure permitted space of low-medium density chalk. Geotech. Lett. 8, No. 4, 298-304, https://doi.org/10.1680/jgele.18.00091.

Alvarez-Borges, F. J., Clayton, C. R. I., Richards, D. J. \& Madhusudhan, B. N. (2018b). The effect of the remoulded void ratio on unit shaft friction in small-displacement piles in chalk. In Engineering in chalk, proceedings of the chalk 2018 conference (eds J. Lawrence, M. Preene, U. Lawrence and R. M. Buckley), pp. 475-480. London, UK: ICE Publishing, https://doi.org/10.1680/eiccf.64072.475.

Been, K., Jefferies, M. G. \& Hachey, J. (1991). The critical state of sands. Géotechnique 41, No. 3, 365-381, https://doi.org/10.1680/ geot.1991.41.3.365.

Bialowas, G. (2017). Time and stress dependent mechanical properties of reconstituted chalk. $\mathrm{PhD}$ thesis, University of Bristol, Bristol, UK.

Bialowas, G. \& Diambra, A. (2018). Time and stress dependent strength and stiffness of reconstituted chalk. In Engineering in chalk, proceedings of the chalk 2018 conference (eds J. Lawrence, M. Preene, U. Lawrence and R. M. Buckley), pp. 503-508. London, UK: ICE Publishing, https://doi.org/10.1680/eiccf. 64072.503 . 
Bialowas, G. A., Diambra, A. \& Nash, D. F. T. (2018). Stress and time-dependent properties of crushed chalk. $P$ I Civil Eng.-Geotec. 171, No. 6, 530-544, https://doi.org/10 1680/jgeen.17.00168.

BSI (1998a). 1377-8:1990. Methods of tests for soils for civil engineering purposes - Part 8: Shear strength tests (effective stress). London, UK: BSI.

BSI (1998b). 1377-2:1990. Methods of test for soils for civil engineering purposes - Part 2: classification tests. London, UK: BSI.

BS-ISO (2009). 13320:2009. Particle size analysis - laser diffraction methods. London, UK: BSI.

Buckley, R. M., Jardine, R. J., Kontoe, S. \& Lehane, B. M. (2018). Effective stress regime around a jacked steel pile during installation ageing and load testing in chalk. Can. Geotech. J. 55, No. 11, 1577-1591, https://doi.org/10.1139/ cgj-2017-0145.

Burland, J. B. (1990a). Preface. In Chalk: proceedings of the international chalk symposium (eds J. B. Burland, R. N. Mortimore, L. D. Roberts, D. L. Jones and B. O. Corbett), pp. 1-4. London, UK: Thomas Telford.

Burland, J. B. (1990b). On the compressibility and shear strength of natural clays, the 30th Rankine Lecture. Géotechnique 40, No. 3 329-378, https://doi.org/10.1680/geot.1990.40.3.329.

Clayton, C. R. I. (1978). Chalk as fill. PhD thesis, University of Surrey, Guildford, UK.

Clayton, C. R. I. (1983). The influence of diagenesis on some index properties of chalk in England. Géotechnique 33, No. 3, 225-241, https://doi.org/10.1680/geot.1983.33.3.225.

Coop, M. R. \& Lee, I. K. (1993). The behaviour of granular soils at elevated stresses. In Predictive soil mechanics, proceedings of the Wroth memorial symposium (eds G. T. Houlsby and A. Schofield), pp. 186-198. London, UK: Thomas Telford.

Cuccovillo, T. \& Coop, M. R. (1993). The influence of bond strength on the mechanics of carbonate soft rocks. In Proceedings of an international symposium on geotechnical engineering of hard soils - soft rocks (eds A. Anagnostopoulos, F. Schlosser, N. Kalteziotis and R. Frank), vol. 1, pp. 447-455. Rotterdam, the Netherlands: AA Balkema.

Desrues, J. \& Ando, E. (2015). Strain localisation in granular media. C.R. Phys. 16, No. 1, 26-36, https://doi.org/10.1016/j. crhy.2015.01.001.

Doughty, L. (2016). Laboratory testing of chalk. MSc dissertation, Imperial College London, London, UK.

Doughty, L., Buckley, R. M. \& Jardine, R. J. (2018). Investigating the effect of ageing on the behaviour of chalk putty. In Engineering in chalk, proceedings of the chalk 2018 conference (eds J. Lawrence, M. Preene, U. Lawrence and R. M. Buckley), pp. 695-701. London, UK: ICE Publishing, https://doi.org/ 10.1680/eiccf.64072.695.

Hancock, J. M. (1975). The petrology of chalk. P. Geologist. Assoc. 86, No. 4, 499-535, https://doi.org/10.1016/S0016-7878(75) 80061-7.

Hobbs, N. B. \& Atkinson, M. S. (1993). Compression and tension tests on an open ended tube pile in chalk. Ground Engng 26, No. 3, 30-34.

Ishihara, K., Tatsuoka, F. \& Yasua, S. (1975). Undrained deformation and liquefaction of sand under cyclic stresses.
Soils Found. 15, No. 1, 29-44, https://doi.org/10.3208/sandf1972. 15.29 .

Kuwano, R. \& Jardine, R. J. (2002). On measuring creep behaviour in granular materials through triaxial testing. Can. Geotech. $J$. 39, No. 5, 1061-1074, https://doi.org/10.1139/T02-059.

Lake, L. M. (1975). Engineering properties of chalk with special reference to foundation design and performance. $\mathrm{PhD}$ thesis, University of Surrey, Guilford, UK.

Leddra, M. J. (1989). Deformation of chalk through compaction and flow. $\mathrm{PhD}$ thesis, University of London (University College London), London, UK.

Leddra, M. J. \& Jones, M. E. (1990). Steady-state flow during undrained loading of chalk. In Chalk: proceedings of the international chalk symposium (eds J. B. Burland, R. N. Mortimore, L. D. Roberts, D. L. Jones and B. O. Corbett), pp. 245-252. London, UK: Thomas Telford Ltd.

Lee, K. L. (1976). Influence of end restraint in cyclic triaxial tests. Vicksburg, MS, USA: United States Department of Defense.

Li, X. S. \& Wang, Y. (1998). Linear representation of steady-state line for sand. J. Geotech. Geoenviron. 124, No. 12, 1215-1217, https://doi.org/10.1061/(Asce)1090-0241(1998)124:12(1215).

Lord, J. A., Twine, D. P. \& Yeow, H. (1994). CIRIA Project report 11: foundations in chalk. London, UK: Construction Industry Research and Information Association (CIRIA).

Lord, J. A., Clayton, C. R. I. \& Mortimore, R. N. (2002). CIRIA report C 574: engineering in chalk. London, UK: Construction Industry Research and Information Association (CIRIA).

Madhusudhan, B. N. \& Baudet, B. A. (2014). Influence of reconstitution method on the behaviour of completely decomposed granite. Géotechnique 64, No. 7, 540-550, https://doi. org/10.1680/geot.13.P.159.

Mesri, G. (1973). Coefficient of secondary compression. J. Soil. Mech. Found.-ASCE 99, No. 1, 123-137.

Puig, J. (1973). Problemes de terrassement dans la craie. Bull. Liaison Labo. P. Ch. 63, No. 1, 56-72 (in French).

Rat, M. \& Schaeffner, M. (1990). Classification of chalks and conditions of use in embankments. In Chalk: proceedings of the international chalk symposium (eds J. B. Burland, R. N. Mortimore, L. D. Roberts, D. L. Jones and B. O. Corbett), pp. 425-428. London, UK: Thomas Telford.

Razoaki, R. N. (2000). Effect of ageing on mechanics of chalk slurries. $\mathrm{PhD}$ thesis, University of Portsmouth, Portsmouth, UK.

Roscoe, K. H., Schofield, A. N. \& Wroth, C. P. (1958). On the yielding of soils. Géotechnique 8, No. 1, 22-52, https://doi. org/10.1680/geot.1958.8.1.22.

Salvatore, E., Modoni, G., Ando, E., Albano, M. \& Viggiani, G. (2017). Determination of the critical state of granular materials with triaxial tests. Soils Found. 57, No. 5, 733-744, https://doi. org/10.1016/j.sandf.2017.08.005.

Vaughan, P. R. (1997). Engineering behaviour of weak rocks: some answers and some questions. In Proceedings of an international symposium on geotechnical engineering of hard soils - soft rocks (eds A. Anagnostopoulos, F. Schlosser, N. Kalteziotis and R. Frank), vol. 3, pp. 1741-1765. Rotterdam, the Netherlands: AA Balkema.

Verdugo, R. \& Ishihara, K. (1996). The steady state of sandy soils. Soils Found. 36, No. 2, 81-91, https://doi.org/10.3208/ sandf.36.2 81 . 